\title{
3 Old Concepts in Changing Societies? Continuities and Transformation of Nationalism in East Germany, 1871-2019
}

\section{Introduction}

After the fall of the Iron Curtain and the end of real existing socialism, it was common to discuss the end of nation states and the era of a transnational order to come. ${ }^{1}$ After a period of globalization and internationalization, nation states played only a minor role in processes of decision-making, economic integration as well as historical development in general. Referrals were repeatedly made to Europe, to name one example here, because the EU significantly represented this global trend. ${ }^{2}$ Thus, when Eric Hobsbawm (1917-2012) wrote a new prologue to the German edition of his famous book Nations and Nationalism since 1780 in 2005, he claimed that nations were disappearing, and that is the time for scientific research because exploring nationalism was possible as recently as the phenomenon had gone. ${ }^{3}$

This perception changed over a couple of years. Several states have renationalized and thus apparently interrupted this development. To describe this process, we only need to mention a few keywords: Brexit, "Make America great again," or border control, and everyone already knows that nationalism is still a vivid political concept. Last but not least, the consequences of the coronavirus as a nightmare for a totally globalized economy led to the complete isolation of individual countries in the northern hemisphere within a few days. The economic and political consequences are not yet foreseeable - a re-nationalization of states cannot be excluded.

1 See, for instance, Rana Dasgupta, "The demise of the nation state," The Guardian, April 5, 2018, https://www.theguardian.com/news/2018/apr/05/demise-of-the-nation-state-ranadasgupta.

2 Etienne Francois, Hannes Siegrist and Jakob Vogel, "Die Nation. Vorstellungen, Inszenierungen, Emotionen," in Nation und Emotion. Deutschland und Frankreich im Vergleich 19. und 20. Jahrhundert, ed. Etienne Francois, Hannes Siegrist and Jakob Vogel (Göttingen: Vandenhoeck und Ruprecht, 1995), 13-14.

3 Eric Hobsbawm, Nationen und Nationalismus. Mythos und Realität seit 1780 (Frankfurt a.M./ New York: Campus, 2006), vii-xiii.

Ә Open Access. ( 2021 Sven Brajer et al., published by De Gruyter. (c))BY-NC-ND This work is licensed under the Creative Commons Attribution-NonCommercial-NoDerivatives 4.0 International License. https://doi.org/10.1515/9783110729290-003 
Therefore, many observers remark that nationalism is coming back today sociology, political sciences, and history assert that re-strengthened nationalism is currently occurring in many places all over the world. However, before we look at this perception, we would like to make some theoretical remarks about nationalism in general.

According to Christian Jansen and Henning Borggräfe, most historians differentiate between two particular manifestations under the term 'nationalism.' On the one hand, it is a "conglomerate of political ideas, feelings and symbols" that "can fit into a closed ideology," but does not necessarily have to. ${ }^{4}$ On the other hand, there are the associated political movements adopting these ideas, emphasizing feelings, and creating new symbols. By demanding a consciousness of nationality, state unity, and sovereignty, ergo a nation state, nationalism socializes as a political movement. After the nation state is built, nationalist groups and movements strive to preserve and regularly also create further internal cohesion in what they consider as the nation. ${ }^{5}$ By doing so, nationalism tries to tie together the different social groups and classes. ${ }^{6}$

Since its beginning, however, nationalism has been an ambivalent concept. Started as a project of emancipation, which was able to overcome stratified societies and to integrate common people into political power, it soon exaggerated and overemphasized ethnic homogeneity as a fundament of national integration and thus drifted off into an "age of extremes," 7 an age of violence. ${ }^{8}$ This development was made possible by the transformation of nationalistic movements into sacral communities, too. By combining several aspects which refer to the monotheistic religions - like the chosen people, the holy land, the enemy inside and outside as well as the historical mission - nationalism obtained, as Hans-Ulrich Wehler highlights, a quasi-religious character and almost became a "political religion." ${ }^{\prime 9}$ Furthermore, nationalism creates

4 Christian Jansen and Henning Borggräfe, Nation - Nationalität - Nationalismus (Frankfurt a.M./New York: Campus, 2007), 18. Still relevant and useful to define the concept: Benedict Anderson, Imagined Communities: Reflections on the Origin and Spread of Nationalism (London: Verso, 1983).

5 Jansen and Borggräfe, Nation, 10-16

6 Ibid., 18.

7 Eric Hobsbawm, The Age of Extremes: A History of the World, 1914-1991 (New York: Vintage Books, 1996).

8 Andreas Fahrmeir, Die Deutschen und ihre Nation: Geschichte einer Idee (Stuttgart: Reclam, 2017), 11.

9 Hans-Ulrich Wehler, Nationalismus: Geschichte, Formen, Folgen (Munich: C.H. Beck, 2001), 27-35. 
emotional communities. ${ }^{10}$ As Borggräfe and Jansen emphasize, most empirical considerations, which focus on "in-groups," show that these communities include or exclude individuals according to their own scale, which creates an exaggerated emotionality. ${ }^{11}$

This was the fundament of more militant developments of nationalist groups and actors. With a view to our subject, we would like to touch on the "völkisch" movement. Stefan Breuer, a sociologist with a special focus on the far right, defines it as "a conglomerate of middle-class ideology, radical nationalism and an ambivalent attitude towards modernity."12 Despite the popular preference for the acceptance of the racial theory at that time, Breuer considers the "Völkischen," i.e. people within the "völkisch" movement, as nationalists because of their unconditional preference with regard to people and nation in their attempt to order society. Thus, he can "avoid corresponding semantics that can be found in word creations such as 'völkisch-rassistisch' or the translation of 'völkisch' with 'racist'."13 But we would like to emphasize that some representatives of the völkish movement were extremely racist. Being nationalist does not exclude being racist at the same time; on the contrary, nationalism and racism were congenial (in German: wahlverwandt), as the historian Christian Geulen convincingly shows. ${ }^{14}$ This discussion underlines that nationalism manifested itself in particular nationalist agents, and some of them acted radically; by overemphasizing the national and defining politics through their national and racial goal(s), radical nationalism became a social reality.

In this contribution, we will focus on the interaction of emotions, imaginations, and practices of nationalism in East Germany. Our main thesis is that East Germany did not reach the transnational age. Nationalism has had a vivid history in East Germany until now. Hence this nationalism changed, and as Geulen recently emphasized, the debate about the re-birth of nations is almost as old as conscious nationalism itself. Inhabitants of the German Empire and contemporary far-right politicians in Germany are united in dreaming of connecting to the glorious past and returning to national strength, which existed

10 For the theoretical background to this term we used: Barbara Rosenwein, Emotional Communities in the Early Middle Ages (Ithaca, NY: Cornell University Press, 2006).

11 Jansen and Borggräfe, Nation, 18.

12 Stefan Breuer, Die Völkischen in Deutschland (Darmstadt: WBG, 2008), 10. Translation by ourselves.

13 Ibid.

14 Christian Geulen, Wahlverwandte. Rassendiskurs und Nationalismus im späten 19. Jahrhundert (Hamburg: Hamburger Edition, 2006). 
and exists only in their imaginations. ${ }^{15}$ Therefore, we will not speak about the return of nationalism. Instead, we would like to highlight a transformation of nationalist ideology, concepts, and discourses. Geulen argues that nationalism transformed continuously and permanently throughout the whole 20th century; the concept and idea of "nationalism" only work as concept and idea; in reality, the world is more complex, as always. ${ }^{16}$

This theoretical background structures our analysis. We would consequently like to give more of an insight into the different manifestations and particular differentiations of nationalism by looking at one example: nationalism in East Germany from 1871 until now; therefore, we focus especially on Saxony and its capital, Dresden. In this city, nationalistic actors and groups were and still are visible in a particular way. We will therefore trace the imaginations of nationhood back to the beginning of the German Empire in 1871. We refer to East Germany as the territories of the former German Democratic Republic (GDR) and less concretely as the region right of the river Elbe. ${ }^{17}$ We do so because several historical studies connect the regional history of East Germany with the rise of radical nationalist parties in Saxony, Thuringia, SaxonyAnhalt, Brandenburg, and Mecklenburg-Vorpommern nowadays, especially in the correlation between votes for the NSDAP in 1933 and the AfD in 2019. ${ }^{18}$

15 Christian Geulen, “Zur 'Wiederkehr' des Nationalismus,” Aus Politik und Zeitgeschichte 68, no. 48 (2018): 4-8.

16 Ibid. Irene Goetz similarly argues that processes of de-nationalization and re-nationalization are ambivalently connected. Irene Goetz, Deutsche Identitäten: Die Wiederentdeckung des Nationalen nach 1989 (Cologne/Weimar/Vienna: Böhlau, 2011).

17 Raj Kollmorgen, Ostdeutschland: Beobachtungen einer Übergangs- und Teilgesellschaft (Wiesbaden: Springer, 2005). See also Thomas Ahbe, "Die Konstruktion der Ostdeutschen: Diskursive Spannungen, Stereotype und Identitäten seit 1989," Aus Politik und Zeitgeschichte 41, no. 42 (2004): 12-22. More controversial is the denomination of Central Germany (Mitteldeutschland), because this term is as fluent as East Germany, and a clear and accepted definition of it does not exist. Furthermore, Central Germany was used as a historical argument to imagine a German Reich that did not exist yet. See Jürgen John, ed., "Mitteldeutschland": Begriff - Geschichte - Konstrukt (Rudolstadt/Jena: Hain-Verlag, 2001). A controversial discussion can be found in Michael Richter, Thomas Schaarschmidt and Mike Schmeitzner, eds., Länder, Gaue und Bezirke: Mitteldeutschland im 20. Jahrhundert (Dresden: Landeszentrale für politische Bildung, 2007).

18 James Hawes, The Shortest History of Germany (London: Old Street Publishing, 2017). Hawes speaks of "Ostelbien," which means the area east of the Elbe. Davide Cantoni, Felix Hagemeister and Marc Westscott, "Persistence and Activation of Right-Wing Political Ideology," Rationality and Competition, Discussion Paper No. 143 (2019). For Saxony in detail, see Uwe Backes and Steffen Kailitz, eds., Sachsen - Eine Hochburg des Rechtsextremismus? (Göttingen: Vandenhoeck und Ruprecht, 2020). 
The question is: does East Germany have its own traditions and particular ideas of nationhood ${ }^{19}$

\section{Nationalism in Germany, 1871-1945}

\section{The German Empire: 1871-1918}

Before the foundation of the Reich, the concept of nation or fatherland referred to its own immediate territory, for example, Saxony or Mecklenburg. ${ }^{20}$ Besides Martin Luther (1483-1546), who was born in Eisleben (today's federal state of Saxony-Anhalt) and who was particularly influential in East and North Germany, it was especially Otto von Bismarck (1815-1898), who came from Schönhausen on the Elbe (also in today's Saxony-Anhalt), who became the national hero of German protestant nationalists after $1871 .{ }^{21}$ From then on, the united German nation served as the founding myth of the Reich. Especially in East Germany, Otto von Bismarck was imagined and venerated as the founder of the Empire. This can also be seen from the following numbers: by around 1900, 240 towers had been built in honor of von Bismarck (so-called Bismarcktürme), some of which stood outside the German Empire, and 174 are still preserved today. Of these, the density is particularly high in eastern Germany; in the territory of the comparatively small state Thuringia, there were 24 of them, in Saxony 23, Saxony-Anhalt 16, Brandenburg 11, and in Mecklenburg-Western Pomerania 4, while in eastern Brandenburg, East Prussia, West Prussia, Pomerania, Poznan and Silesia, which today belong to Poland, there was a total of 40. In comparison, there were only 13 such monuments in the large German states of Bavaria and only 9 in Baden-Württemberg. ${ }^{22}$ Bismarck and the specifically "German," unifying nationalism initiated in Prussia found its most loyal followers in East Germany, in contrast to South or Southwest Germany, and the Bismarck celebrations at these

19 This was recently argued by Ilko-Sascha Kowalczuk. See Ilko-Sascha Kowalczuk, Die Übernahme. Wie Ostdeutschland Teil der Bundesrepublik wurde (Munich: C.H. Beck, 2019), 215-233.

20 Fahrmeir, Die Deutschen und ihre Nation, 70-97.

21 Rainer Lächele, "Protestantismus und Völkische Religion im deutschen Kaiserreich" in Handbuch zur "Völkischen Bewegung” 1871-1918, ed. Uwe Puschner, Walter Schmitz and Justus H. Ulbricht (Munich: KG Saur, 1999), 149-163; Christopher König, Zwischen Kulturprotestantismus und völkischer Bewegung: Arthur Bonus (1864-1941) als religiöser Schriftsteller im wilhelminischen Kaiserreich (Tübingen: Mohr Siebeck, 2018), 26-61.

22 Jörg Bielefeld, "Bismarcktürme- und Bismarcksäulen. Das Infoportal Bismarcktürme," accessed July 7, 2020, https://www.bismarcktuerme.de/index.html. 
memorials were often visited by numerous people - today, local activists "rediscover" them uncritically and build them up as destinations for excursions or locations for celebrations of various kinds. ${ }^{23}$ Even the politicians of the AfD have a special affection for Bismarck, like the Thuringian state chairman Björn Höcke. His party referred to Bismarck on an election poster, which is subtitled with the slogan "His role model is our obligation."24

In East Germany, Protestantism was a second unifying bond that stretched from the Baltic Sea to the Ore Mountains (Figure 1). In addition, an increasing heroization of ancient Greece in art and culture played a major role and had a big impact on cultural-imperial practices. For example, the biography of the Dresden völkish sculptor and painter Richard Guhr (1873-1956) is representative of conservative artists, politicians, scientists, doctors, civil servants, merchants, craftsmen typical representatives from the old middle class. Guhr had become a nationalistic anti-Semite at the latest by 1918 with the decay of the empire founded by von Bismarck in 1871. He demonstrated this in various pamphlets, but above all in his paintings between 1912 and $1933 .^{25}$

Guhr was born in the town of Schwerin (Mecklenburg) and socialized there. He had a middle-class educational background and did his military service voluntarily. From the 1890s on, he lived in Berlin and Dresden, from 1914 until 1945 exclusively in the Saxon capital. ${ }^{26}$ All these cities had a clear Protestant majority.

Guhr saw himself in the tradition of the ancient philosophers. ${ }^{27}$ Even today in Dresden, the most famous sculpture of the demigod Heracles, erected in 1908

23 One of the authors was allowed to experience this in the contemplative EbersbachNeugersdorf, district Neugersdorf, Eastern Saxony; see Jenny Thümmler, "Heimatverein lädt zur Bismarckfeier,” Sächsische Zeitung GOS Görlitz Lokales, March 31, 2015, https://www.saech sische.de/plus/heimatvereinlaedt-zur-bismarckfeier-3072675.html.

24 Ulrich M. Schmid, "Bismarck, eine Karriere - der «eiserne Kanzler» wird in Deutschland immer noch zu wenig kritisch gesehen,” Neue Zürcher Zeitung, January 20, 2020, https://www. nzz.ch/meinung/bismarck-eine-karriere-der-eiserne-kanzler-wird-in-deutschland-immer-nochzu-wenig-kritisch-gesehen-ld.1532085.

25 Richard Guhr, Der Judenstil oder der Expressionismus (Dresden: Max Emil Fischer, 1922); Richard Guhr, Die Schuld am Verfall der Künste (Dresden: Fischer, 1923). The most important pictures, which were largely destroyed in the bombing of Dresden on 13-14 February 1945, can be found in the illustrated book: Ernst Köhler-Hausen, ed., Aus der Dresdner Wagner-Ehrung im Schloss Albrechtsberg (Dresden: Stadtmuseum, 1939).

26 Ruth Stummann-Bowert, Ein Leben für Richard Wagner: Richard Guhr: Maler und Bildhauer 1873-1956 (Fritzlar: Stiftung Museum Fritzlar, 1988), 209.

27 Barbara Stiewe, Der "Dritte Humanismus": Aspekte deutscher Griechenrezeption vom GeorgeKreis bis zum Nationalsozialismus (Berlin/Boston: De Gruyter, 2011), 88-123, 159-163, 185-188, 198-200, 223-232. 


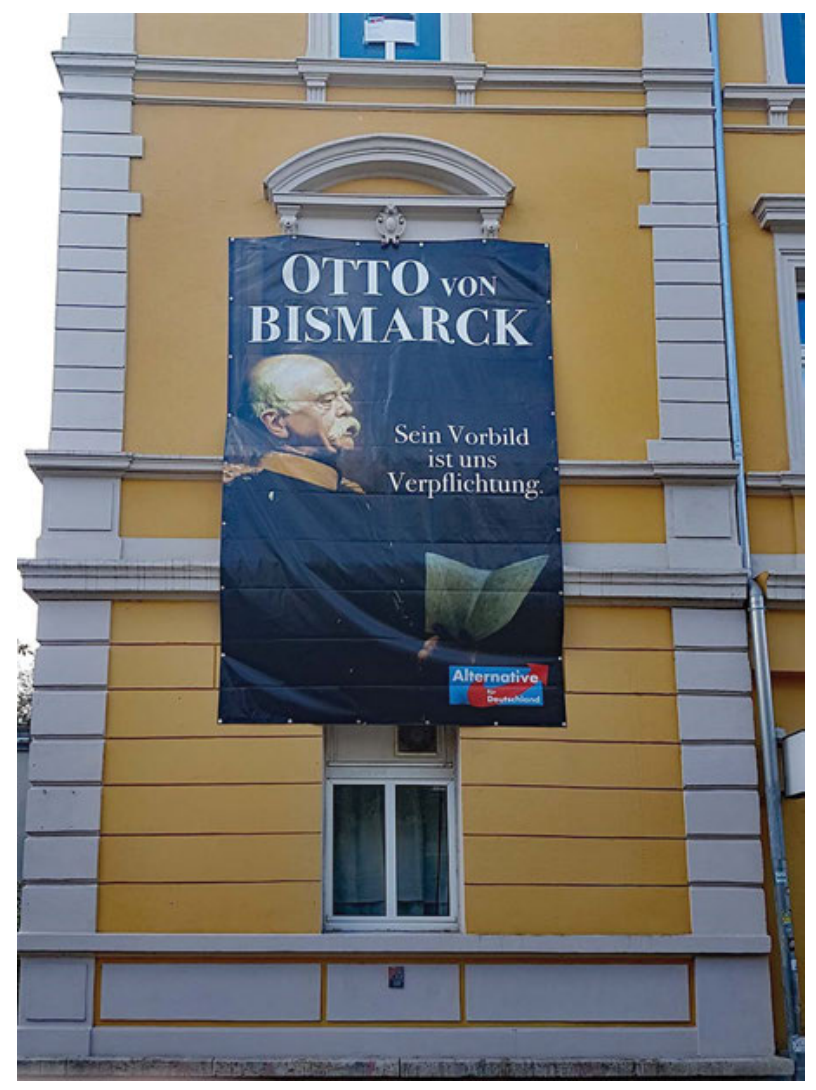

Figure 1: AfD Bundestagswahlplakat, Weimar, Thüringen 2017 (Andreas Werner).

by Guhr, the so-called "Golden Town Hall Man" on the tower of the New Town Hall, stands out impressively from Guhr's great creative period (Figure 2). For Guhr, Heracles was symbolically considered a demigod and, inspired by Friedrich Nietzsche, as an Übermensch. The art historian Ruth Stummann-Bowert interprets the demigod on the one hand as a völkish manifestation and on the other as an educational theme, which was particularly suited to the Dresden court; he was supposed to symbolize the protection of the population of the city. ${ }^{28}$

28 Stummann-Bowert, Ein Leben für Richard Wagner, 12, 172. See also Johann Chapoutot, Greeks, Romans, Germans: How the Nazis Usurped Europe's Classical Past (Berkeley: University of California Press, 2016), 165. 


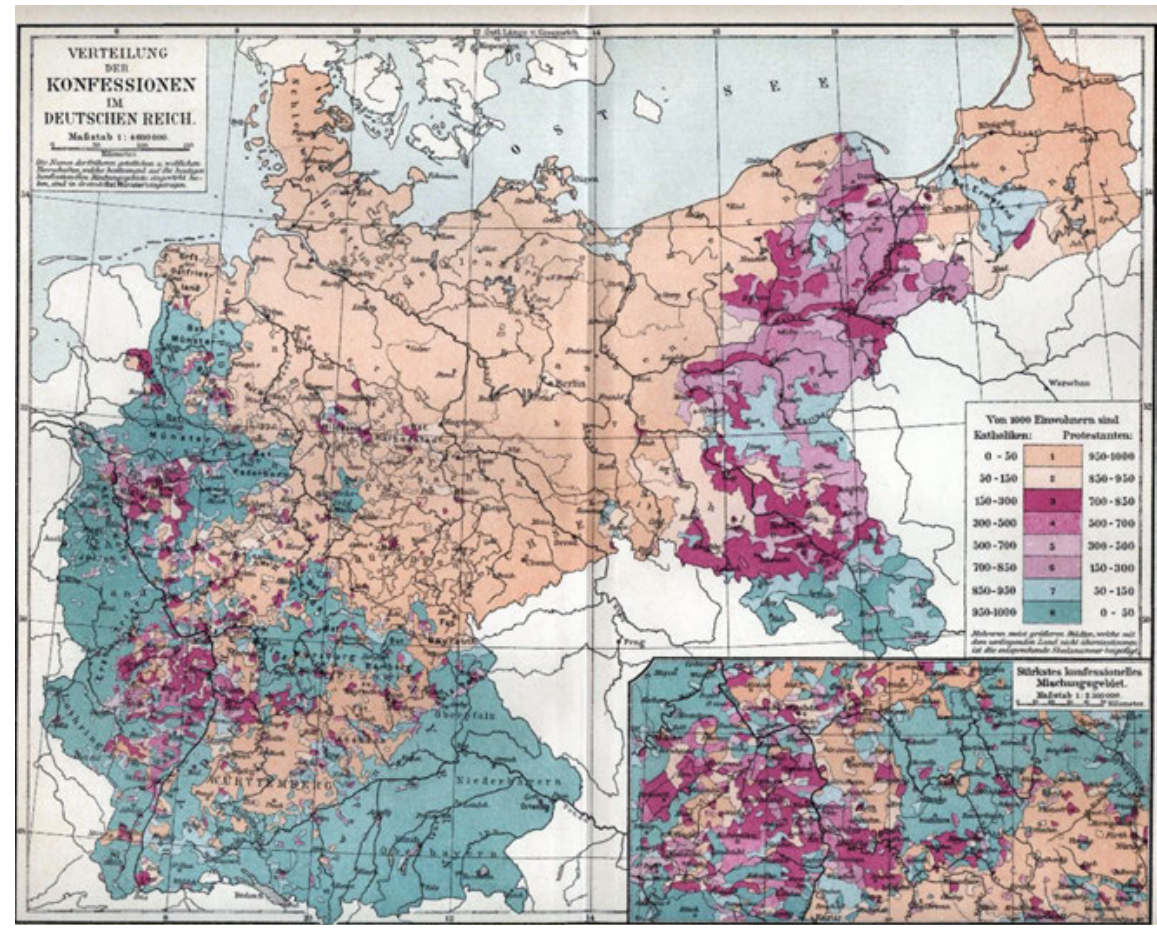

Figure 2: The spread of confessional denominations in the German Empire (Meyers Konversationslexikon, 5th ed., 1897).

A few years later, in 1911/12, Guhr made an esoteric fasting cure, ${ }^{29}$ which ended with a trip to the grave of the famous composer Richard Wagner (1813-1883) in Bayreuth. ${ }^{30}$ Shortly afterward in 1912/13, he built the biggest Richard Wagner monument worldwide, which was erected and inaugurated in 1933 in the Liebethaler Grund in Saxon Switzerland by the Nazis (Figure 3).

29 For the "crisis year" of 1912 for the völkish, see Frank Jacob, Die Thule-Gesellschaft und die Kokuryûkai: Geheimgesellschaften im global-historischen Vergleich (Würzburg: Königshausen \& Neumann, 2013), 103.

30 Richard Guhr, Das Problem der erotischen Regeneration (1912) in Stummann-Bowert, Ein Leben für Richard Wagner, 220-224, quotation 220. 


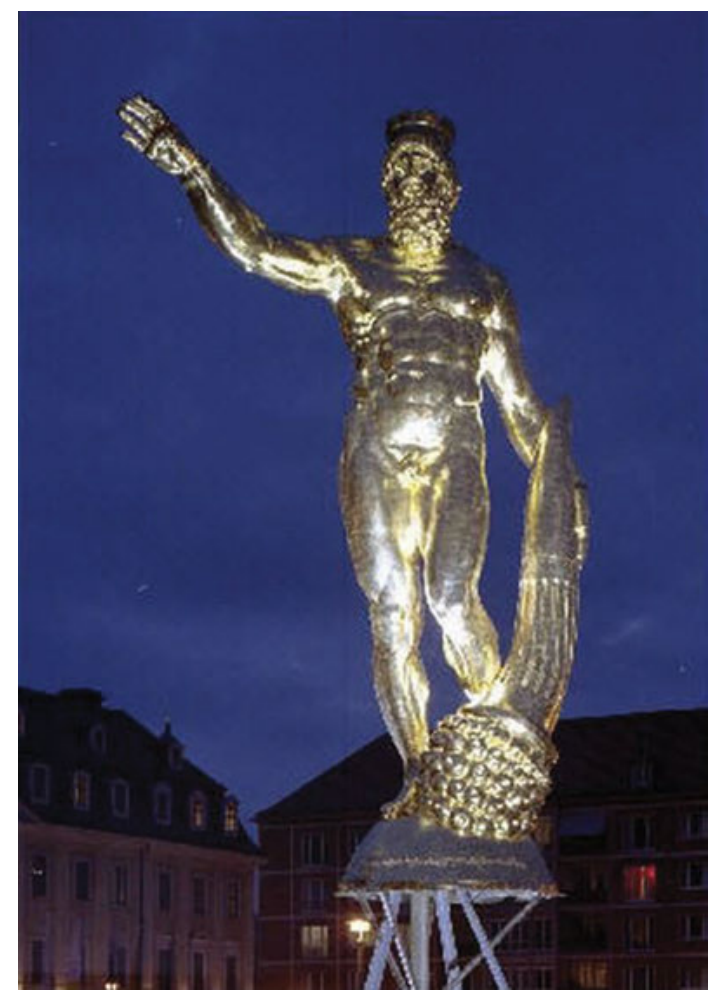

Figure 3: "Goldener Rathausmann" (1908-1910; R. Guhr) after restoration, standing on the green area in front of the New Town Hall, Dresden. Photo by Siegfried Bregulla, 2006 (Deutsche Fotothek).

Wagner's Bayreuth acted as a German(ic) "Sehnsuchtsort" (place of longing) for many people, such as Houston Stewart Chamberlain (1855-1927) and Adolf Hitler (1889-1945). ${ }^{31}$ Alongside Luther's and Bismarck's influences, Wagner's “Weltanschauung"32 (worldview) served as a further pillar in the national-protestant cosmos. Guhr regarded Wagner's Scriptures as a key to a supposed "Aryan regeneration,"33 a völkish-teleological ideology. For Guhr, Wagner, and numerous other

31 Udo Bermbach, Richard Wagner in Deutschland: Rezeption - Verfälschungen (Stuttgart/Weimar: Metzler, 2011), 429-470.

32 Rudolf Louis, Die Weltanschauung Richard Wagners (Leipzig: Breitkopf \& Härtel, 1898); see also Josef Lehmkuhl, Der Kunst-Messias: Richard Wagners Vermächtnis in seinen Schriften (Würzburg: Königshausen \& Neumann, 2009), especially 187-220.

33 On this term and its origin see Solveig Weber, Das Bild Richard Wagners: Ikonographische Bestandsaufnahme eines Künstlerkults, vol. 1: Text (Mainz: Schott, 1993), 171, 250. 
conservative nationalists, who often lived in the protestant regions of East Germany, ${ }^{34}$ the German himself was considered as the rebirth of the Aryan. He above all was to break away from the supposed embrace of the so-called golden international banking and financial capital on the one hand and the red international social democrats, communists, and anarchists on the other, which, according to the interpretation of the völkish movement, was clearly dominated by Jews. ${ }^{35}$ With the exception of the area of Posen, Berlin, Leipzig, and some cities in Silesia, the proportion of the Jewish population in eastern Germany was significantly lower than in the German Empire on the left side of the Elbe. ${ }^{36}$ The barely visible enemy image of the "Jew," especially contrasted to the "German," was suitable for the paranoia of an entire generation. ${ }^{37}$

As a result, numerous nationalist and völkish clubs, associations, and cultural institutions were founded in East Germany: in 1881 the "Deutsche Reformpartei,"38 in 1885 the "Allgemeine Deutsche Sprachverein,"39 in 1920 the "Deutsche Kunstgesellschaft," ${ }^{\circ 0}$ and finally in Hellerau (near Dresden), almost simultaneously in 1919/ 20, the "Deutsche Bauernhochschule" under the guidance of Bruno Tanzmann (1878-1939). ${ }^{41}$ The last one in particular emerged as an antiurban völkisch movement.

Theodor Fritsch (1852-1933), probably the most well-known and journalistically active anti-Semite of the German Empire, lived in Leipzig. He acted as an initiator of the journal Der Hammer: Blätter für deutschen Sinn (The Hammer: Sheets for the German Sense, 1902-1940), the “Germanenorden” (Germanic Order) in 1912, ${ }^{42}$

34 Hawes, The Shortest History, 193-194.

35 This is the antisemitic sound of the Deutsche Wacht: Organ für nationale Politik; Publikationsorgan der völkischen Vereine Sachsens (Dresden: Verlag der Deutschen Wacht Volumes, 1879-1933).

36 Steven M. Lowenstein et al., Deutsch-jüdische Geschichte in der Neuzeit: Umstrittene Integration 1871-1918 (Munich: C.H. Beck, 1996), 29-32.

37 Max Bewer, Der Rembrandtdeutsche. Von einem Wahrheitsfreund (Dresden: Glöß, 1892), 97.

38 Founded as anti-Semitic Reform association in 1879, the party quickly spread to Eastern Saxony and Silesia. Matthias Piefel, Antisemitismus und völkische Bewegung im Königreich Sachsen (Göttingen: V\&R Unipress 2004), 37; Sven Brajer, "Angst vor dem Fremden in Zeiten des Umbruchs? Aspekte von Antisemitismus und Rassismus im Kaiserreich in der Oberlausitz,” Neues Lausitzisches Magazin 141 (2019): 81-92.

39 Deutschen Sprachverein Dresden and Hermann Dunger, eds., Satzungen des Deutschen Sprachvereins. Neue Fassung von dem Beschlusse vom 17. Januar 1889 (Dresden: Teich, 1889).

40 A central pioneer of the concept of national socialistic art. Bettina Feistel-Rohmeder, "Kurzer Rückblick auf die Entstehung und Entwicklung der Deutschen Kunstgesellschaft,” in Im Terror des Kunstbolschewismus. Urkundensammlung des "Deutschen Kunstberichtes” aus den Jahren 1927-33 ed. Bettina Feistel-Rohmeder (Karlsruhe: Müller, 1938), 211-217.

41 Bruno Tanzmann, “Zur Einleitung. Aus meinem Leben als völkischer Vorkämpfer," in Plan des Hochstiftes für Deutsche Art in Hellerau, vol. 1, ed. Deutsche Bauernhochschule (1926), 5.

42 Frank Jacob, Die Thule-Gesellschaft (Berlin: uni-edition, 2010), 27-32; Jacob, Die ThuleGesellschaft und die Kokuryûkai, 105-110, Damien Guillaume, "Vers 'l'agitation antisémitique' 
and the "Sächsische Mittelstandsvereinigung" (Saxon Middle-Class Association) in 1905. The "Harzer Bergtheater," the first outdoor theatre in the Reich, originated in the Harz region, in Thale in 1903, initiated by the anti-Semite Ernst Wachler. ${ }^{43}$ In 1924 the Artamans were founded in Limbach, Western Saxony, and were deeply involved with Tanzmann's Bauernhochschule. The exclusive and ideologically leading "Deutschbund" (German Federation) had its headquarters in Berlin, just like the nationalist "Deutsche Kolonialgesellschaft" (German Colonial Society) ${ }^{44}$ and the Deutschnationale Völkspartei (DNVP, German National People's Party), founded in 1918. ${ }^{45}$ In Posen (Poznań), the anti-Polish "Ostmarkenverein” (Eastern Border Association) had existed since $1894 .^{46}$ In addition to the anti-Semitism described above, all these groups more or less vituperated against the Slavs, who were equated with primitive, "inferior" peasants, against Rome (the Catholic Church), against the French (especially the arts), and more or less against English liberalism and mercantilism ("Manchestertum"). ${ }^{47}$ All these clubs and organizations, the artists and their benefactors, the media and the public opinion represent the widespread dissemination of radical nationalism crossed with aggressive racism in Eastern Germany during the Empire: all of them imagined Germany as a nationally and racially homogenous nation state under threat from inner and outer enemies, and they were more than willing to defend their nation, no doubt even with violence.

comme phénomène transnational: hostilité antijuive, équivoques libérales et solidarité juive internationale de l'Affaire Mortara au Congrès de Berlin (1858-1878)," in Antisemitismus im 19. Jahrhundert aus internationaler Perspektive: Nineteenth Century Anti-Semitism in International Perspective, ed. Mareike König and Oliver Schulz (Göttingen: V\&R Unipress, 2019), 313.

43 Uwe Puschner, "Deutsche Reformbühne und völkische Kultstätte. Ernst Wachler und das Harzer Bergtheater," in Handbuch zur "Völkischen Bewegung” 1871-1918, ed. Uwe Puschner, Walter Schmitz and Justus H. Ulbricht (München: Saur 1996), 762-796.

44 Reiner Fenske, Imperiale Verbände im Deutschland der Zwischenkriegszeit im Vergleich. Die Beispiele des "Deutschen Ostbundes" und der "Deutschen Kolonialgesellschaft" (Dresden: Diss, 2018).

45 Maik Ohnezeit, Zwischen "schärfster Opposition" und dem "Willen zur Macht” - Die Deutschnationale Volkspartei (DNVP) in der Weimarer Republik 1918-1928 (Düsseldorf: Droste, 2011); Thomas Mergel, "Das Scheitern des deutschen Tory-Konservatismus. Die Umformung der DNVP zu einer rechtsradikalen Partei 1928-1932,” Historische Zeitschrift 276 (2003): 323-368.

46 Christoph Kienemann, Der koloniale Blick gen Osten. Osteuropa im Diskurs des Deutschen Kaiserreiches von 1871 (Paderborn: Schöningh, 2018).

47 For Dresden in particular, see the powerful local group of the Alldeutscher Verband who fought all these enemy images: Gerald Kolditz, "Rolle und Wirksamkeit des Alldeutschen Verbandes in Dresden zwischen 1895 und 1918: ein Beitrag zum bürgerlichen Vereinsleben der nationalistischen Kräfte in der wilhelminischen Ära des deutschen Kaiserreiches” (PhD diss., TU Dresden, 1994). 


\section{Weimar and Beyond: 1918-1945}

The years 1933 and beyond were the peak of the nationalistic dream. And they kept their dreams alive during the Weimar years. Again, Richard Guhr witnesses that the nationalist movement thought of the German community as a united ethnos, as a community of people, as the German "Völksgemeinschaft." ${ }^{8}$ This picture, “Germania 1918/Ultima ratio,” (Figure 4) was painted by Guhr in 1919 or 1920. Ernst Köhler-Hausens, a journalist and friend of Guhr who also lived in Dresden, gave the following description in the year 1938:

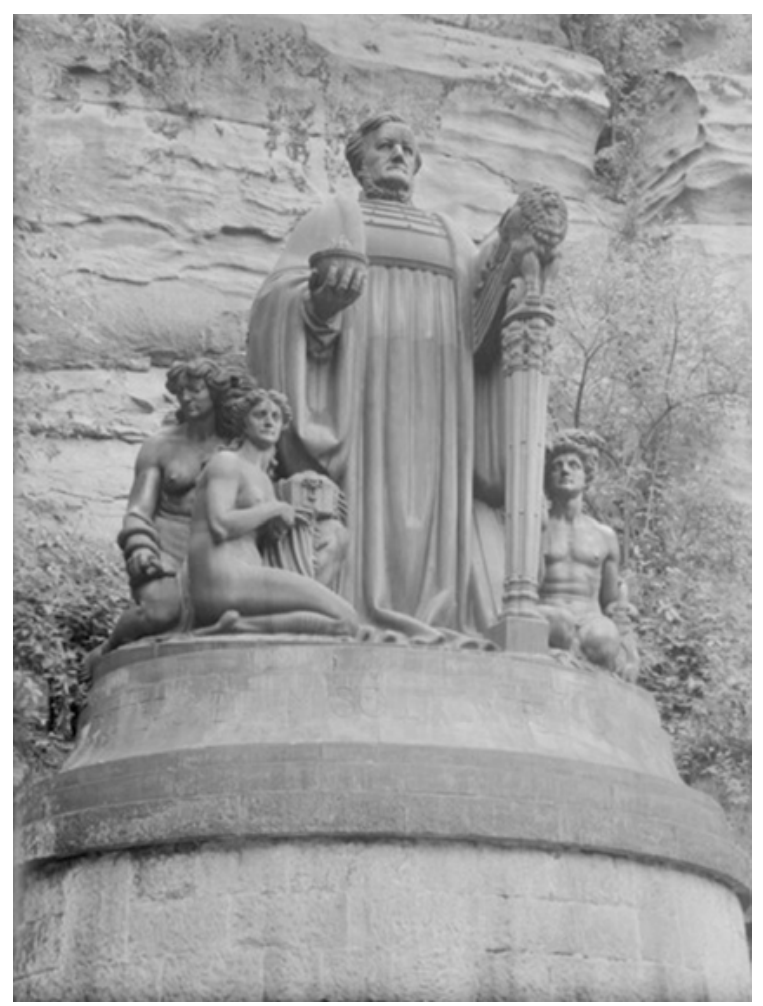

Figure 4: Richard-Wagner-Monument at Liebethaler Grund, Saxony. Photo by Walter Möbius, 1933 (Deutsche Fotothek).

48 For the latest on this crucial historical term, see Michael Wildt, Volk, Volksgemeinschaft, AfD (Hamburg: Hamburger Edition, 2017). 
Our feet in chains, we see Germany collapsing in despair on a hill on the Rhine plain. The Jewish star [sic!] with Jehovah's sign threatens to rule over it; terrified ravens ${ }^{49}$ flutter around it. Only one has remained: the blue flower, which represents faith in the powers of the heart and the soul, no matter whether we see in it the blue flower of romanticism or a parable for the Aryan-Germanic quality of loyalty to one's own being. From the German landscape, the forest on the mountain, a torrent of fog streams down, which forms itself into a white snake, the symbol of blessed, secret powers; it is crowned by a new temple, a parable for the fact that a new faith of mankind can regain salvation from the Aryan being. ${ }^{50}$

This description sounds strongly like an arrangement with the artist, Guhr: Germany, as the mother Germania in black with a mourning veil on a hill in the Madonna position, shows the much-described shocked rigidity of nationalist and völkish forces after the lost war. The chained feet, the wreath of thorns, and the Star of David with the inscription "Yahweh," which was removed after 1945 by Guhr's widow, Hedwig, clearly name Judaism as the guilty party for the defeat. At the same time (1918/19), according to Guhr, Jewry had also become the new master in Germany. Presumably, the gentian, as the flower of loyalty, and the legendary snake, possibly to be interpreted as the Rhine (the German river par excellence), show the way to the supposed Aryan regeneration of Germany.

The Weimar Republic, symbolically disparaged here by Guhr, was considered a catastrophe by a large part of the German population, from the center to the far right. With the lost war and the revolution of 9 November 1918, which was mainly formed by workers and soldiers, this perception led to a briefly shocked rigidity for those people. And also, from the center to the far right, the Treaty of Versailles was rejected and attacked as a product of an international conspiracy by which Germany was solely to blame for the war. By inventing this master narrative, the heterogeneous nationalistic groups and actors united and formed a resistance. Thus, the DNVP was founded in Berlin in 1918, with bastions mainly in East Prussia, Mecklenburg, Pomerania, and Saxony. In a poster of the party from the Reichstag elections in 1920 (Figure 5), the DNVP is depicted as a submarine from the First World War with the flag of the empire torpedoing the merchant ship of the Weimar Republic with the black-red-gold flag. The torpedo represents the Reichstag election. The phrase means: "It must hit." The Weimar Republic is embodied by "Schiebertum" (racketeerdom, representing the "Golden International" and liberalism) and Bolshevism (representing the "Red International" and communism); both terms were used with explicit anti-Semitic connotations.

49 Ravens were the messengers of fate of the old Germanic god Wotan.

50 Köhler-Hausen, Aus der Dresdner Wagner-Ehrung im Schloss Albrechtsberg, 6. 


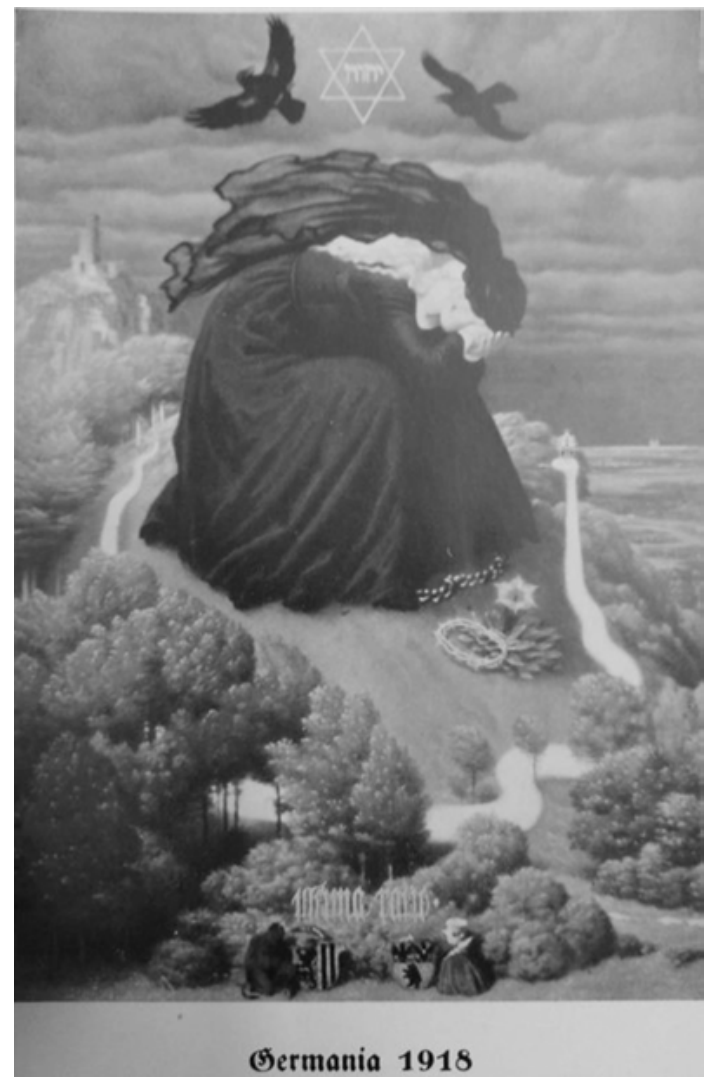

Figure 5: “Germania 1918/Ultima ratio" by Richard Guhr.

The Nationalsozialistische Deutsche Arbeiterpartei (NSDAP, National Socialist German Workers' Party), founded in Munich in 1920, had its first success outside Bavaria in the early 1920s. In Saxony, especially in the area in the southwest around Zwickau and Plauen, lots of unemployed craftsmen and factory workers were hit by the economic crises after the First World War. ${ }^{51}$ From

51 Andreas Wagner, “Machtergreifung” in Sachsen: NSDAP und staatliche Verwaltung 1930-1935 (Cologne: Böhlau, 2004), 31-39 Also see: Günther Heydemann, Jan Erik Schulte and Francesca Weil, "Sachsen und der Nationalsozialismus: Zur Vielfalt gesellschaftlicher Teilhabe - Einführung," in Sachsen und der Nationalsozialismus, eds. idem (Göttingen: Vandenhoeck \& Ruprecht, 2014), 9-19. 


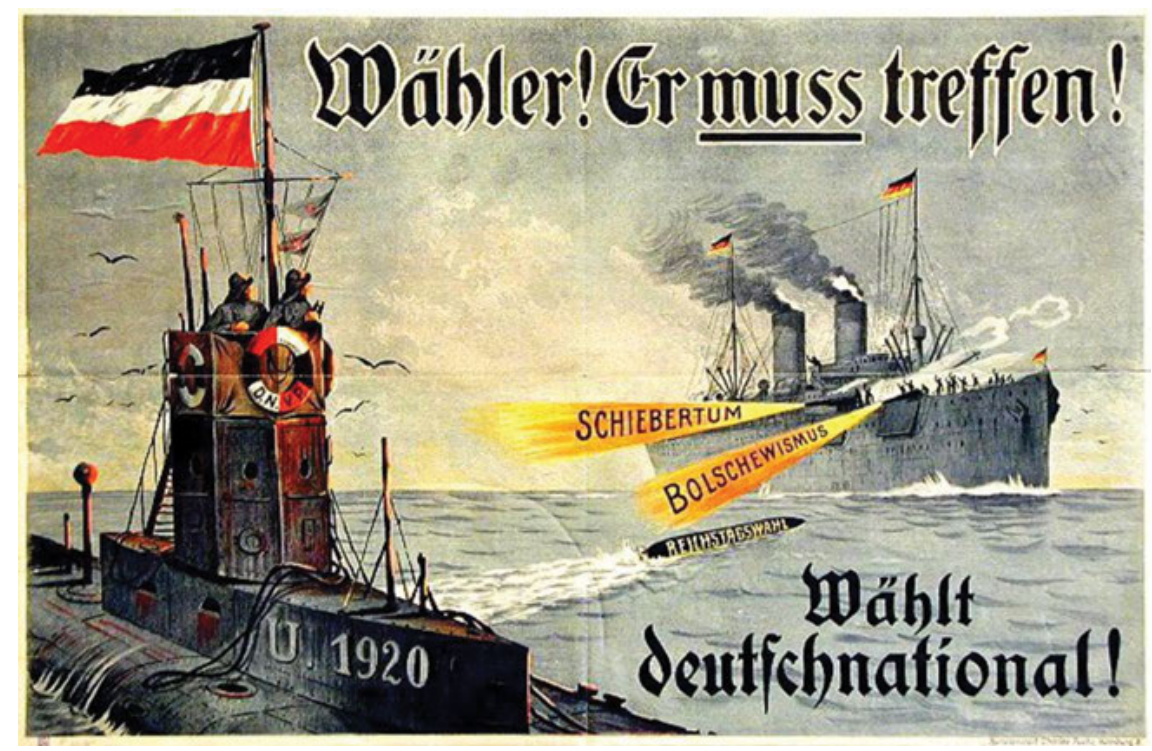

Figure 6: DNVP poster on the Reichstag election, 1920, (C) Deutsches Historisches Museum, Berlin Inv. No.: P 57/98.

there on, the party had more and more success in East and North Germany, increasingly displacing the less radical DNVP. It had important centers in Mecklenburg-Schwerin, Pomerania, (East) Prussia, Anhalt, Saxony, and Thuringia (Figure 6). In the latter, with the formation of the "Baum-Frick government" at the beginning of 1930, the NSDAP provided two government posts in a federal state government for the first time in the Weimar Republic. Wilhelm Frick (1877-1946), who later became Reichsminister of the Interior, was appointed Minister of the Interior and Education in Thuringia. ${ }^{52}$ This first-ever participation in a government by the National Socialists was expressly praised by Adolf Hitler as a great success and represented a field of experimentation for him. In the years after, the national socialistic "Machtergreifung," the socialization and general implementation of the

52 Alexandra Esche, Hitlers “völkische Vorkämpfer”. Die Entwicklung nationalsozialistischer Kulturund Rassenpolitik in der Baum-Frick-Regierung 1930-1931 (Berlin/New York: Peter Lang), 2017. 
national socialist worldview into German society, the war, and the Holocaust were the most extreme manifestations of the aspiration for a homogenous and ethnically "pure" nation in conjuncture with the imagination of the nation being attacked by different domestic and foreign enemies.

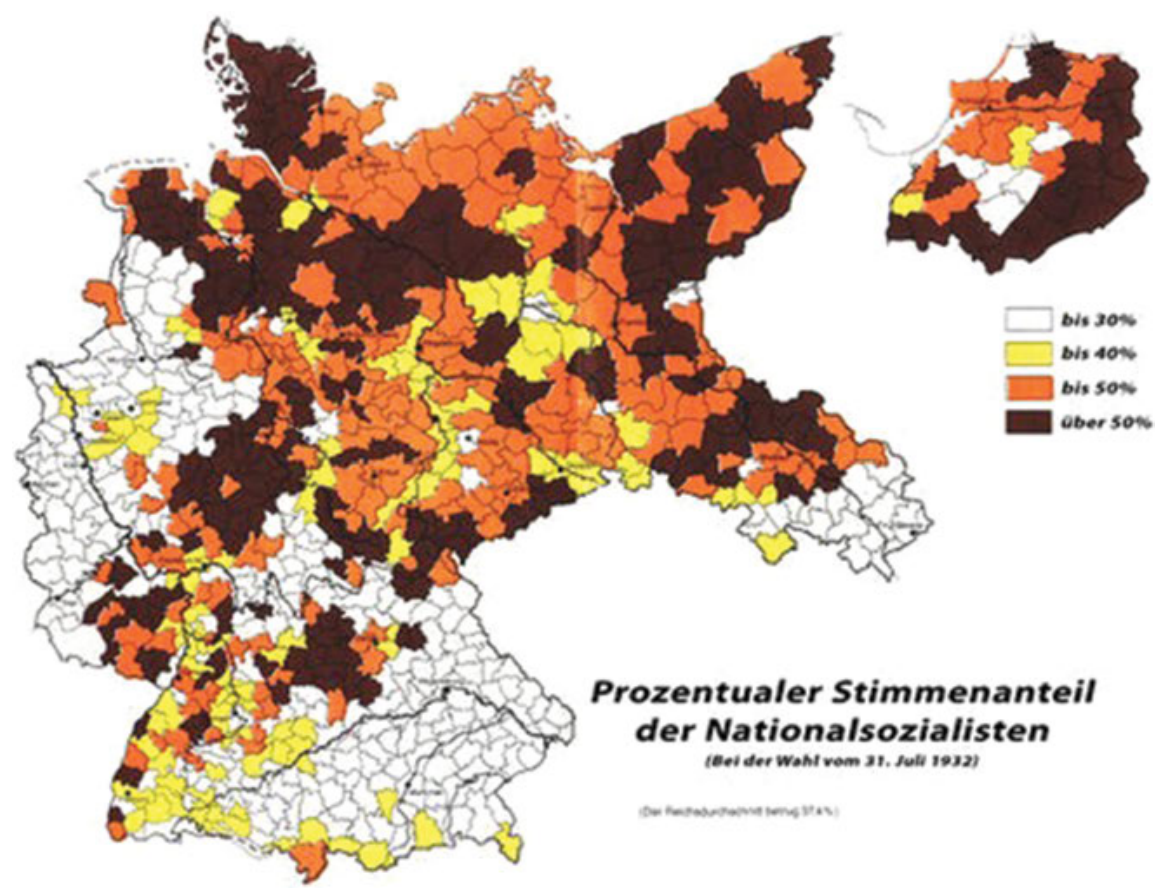

Figure 7: Percentage of National Socialist votes in the Reichstag elections on 31 July 1932.

While their personnel and followers had still formed from the numerous associations of the fatherland associations of the empire (military associations, Alldeutscher Verband, etc.), the Nazis had much younger personnel, ${ }^{53}$ who were surprisingly often allowed to indulge in their authoritarian worldviews even in the Sowjet Occupational Zone and the later GDR, despite the strict denazification by the Soviets. Three prominent examples from different generations are referred to here. Willy Gehler (1876-1953), Professor of Civil Engineering at the Technical University of Dresden, who had been a member of the NSDAP and SS since 1933,

53 Ulrike Jureit, "Ein Rhythmus der Geschichte? Generationsgeschichtliche Deutungsmuster zum 20. Jahrhundert," in Detlev Peukert und die NS-Forschung, ed. Rüdiger Hachtmann and Sven Reichardt (Göttingen: Wallstein, 2015), 88-94. 
was able to continue his research there after 1945, although in a less high position. ${ }^{54}$ Bodo Uhse (1904-1963) was active on the völkish scene in Southern Germany from 1921, and was a member of the NSDAP from 1927 to 1930, and later of the KPD, and in 1949 he joined the SED. From 1950 to 1954, Uhse was, among other positions, a member of the SED in the Völkskammer and from 1950 to 1952 first chairman of the German Writers' Association in the Cultural Association for the Democratic Renewal of Germany. ${ }^{55}$ Finally, Hans Bentzien (1927-2015) joined the NSDAP in 1944 and was later the first district secretary of the SED in Jena, Gera, and Halle and was to rise to the position of Minister of Culture of the GDR. ${ }^{56}$ These three, as well as all the unnamed exponents of the nationalistic movement that later became part of the NSDAP, connect the pre- and postwar eras. They transferred and transformed, in a more or less hidden way, ideas about the nation and embedded them into the "new society." Thus, nationalism nowadays has its one tradition rooted in the GDR as well as in the nationalistic movements and parties before 1945.

\section{Hidden and Open Nationalism from 1945 until the Present}

Nationalism was not dismissed in some German regions that are congruent with the GDR. Instead, the idea of the nation has always been a powerful political resource. However, the question is: what is different from the years before 1945 ?

In 1945, the German Empire was defeated and divided into different parts, from which emerged two states: the Federal Republic of Germany (FRG) in the western zones and the German Democratic Republic in the eastern zone. In the

54 Manfred Curbach, Thomas Hänseroth and Oliver Steinbock, "Willy Gehler in der Triade aus Wissenschaft, Industrie und Verwaltung," in Mit den wohlfeilsten Mitteln dauerhaft, feuersicher und bequem. Sparsamkeit als Prinzip, Rationalität als Weltsicht, ed. Gesellschaft für Bautechnikgeschichte (Dresden: Thelem, 2019), 245-261.

55 Wolfgang Bauer, "Nachdenken über Bodo Uhse,” Das Blättchen, 16, no. 14 (July 2013), accessed July 7, 2020, https://das-blaettchen.de/2013/07/nachdenken-ueber-bodo-uhse-25720. html.

56 Sandra Meenzen, “'Gutes Klassenbewusstsein, Parteiverbundenheit und Prinzipienfestigkeit': SED-Sekretäre mit NSDAP-Vergangenheit in Thüringen” [“Class consciousness, party alignment and adherence to Principles”: Thuringian SED party secretaries with a NSDAP past], Historical Social Research 35, no. 3 (2010): 59-63. 
SBZ/later GDR, a socialist Germany would be created. ${ }^{57}$ The claim of the communist leaders was clear. They emphasized loudly that after the National Socialists had taken the Germans hostage and plunged Europe into a destructive war, they would establish a self-determined government of the German people under anti-fascist and socialist auspices. ${ }^{58}$ Nevertheless, the "nation" continued to form a self-evident and unquestioned reference point of their policy.

The SED, however, changed its conception of the nation several times by emphasizing different aspects of nationhood. Therefore, the discussion about the national character of the socialist country, the GDR, was correspondingly complex. ${ }^{59}$ Immediately after the founding of the socialist state and during the early 1950s, leading representatives of the SED addressed the nationalist worldviews among the population. They heard that after Hitler's fascism, it was now US imperialism that wanted to subject Germany. The SED resolutely opposed this and offered the entire German people a life of freedom, peace, and unity. The party tried to work for a national unity in a socialist order and did not shy away from using explicitly nationalistic language. ${ }^{60}$

Thus, the SED staged itself as the only legitimate representative of the interests of the German people at the beginning of the GDR. In 1969, the references to the nation changed, and this was due to what historians call the "German-German" relationship and negotiations of the so-called "Nationale Frage" (national question). Politicians, especially those from the FRG, attacked the German division and strove for German unification. Challenged by the Federal Republic's propaganda that a uniformly German "Kulturnation" (cultural nation) would outlast the German division, the East German leaders started to construct and spread a new notion of the nation. ${ }^{61}$

57 Ulrich Herbert, Geschichte Deutschlands im 20. Jahrhundert (Munich: C.H. Beck, 2014).

58 Sigrid Meuschel, Legitimation und Parteiherrschaft: Zum Paradox von Stabilität und Revolution in der DDR, 1945-1989 (Frankfurt: Suhrkamp, 1992); Aleida Assmann and Ute Frevert, Geschichtsvergessenheit-Geschichtsversessenheit: Vom Umgang mit deutschen Vergangenheiten (Stuttgart: Deutsche Verlagsanstalt, 1999).

59 Joanna McKay, The Official Concept of the Nation in the Former GDR: Theory, Pragmatism and the Search for Legitimacy (Aldershot: Ashgate, 1998). In a nutshell: Reinhart Koselleck, "Volk, Nation. XV. Ausblick 1945-1991," in Geschichtliche Grundbegriffe: Historisches Lexikon zur politisch-sozialen Sprache in Deutschland, vol. 7, ed. Otto Brunner (Stuttgart: Klett-Cotta, 2004), 420-430.

60 Michael Lemke, "Nationalismus im Deutschlandkonzept der SED 1949-1955," in Nationalismus in Europa nach 1945, ed. Heiner Timmermann (Berlin: Duncker und Humblot, 2001), 41-58.

61 Heike Amos, Die SED-Deutschlandpolitik 1961-1989: Ziele, Aktivitäten und Konflikte (Göttingen: Vandenhoeck \& Ruprecht, 2015); Gunther Mai, "Sozialistische Nation und Nationalkultur," 
The leading party in the GDR party broke away from the idea of an indivisible German nation and proclaimed the development of two separate nations. Numerous social theorists defined a new national order for the GDR and FRG. ${ }^{62}$ The state division of the German Empire not only produced two German states, but also split the formerly uniform nation into a capitalist nation in the west and a socialist nation in the east. Not only were the ethnic, linguistic, and cultural similarities seen as decisive for the national character, but the socio-economic order or, materialistically speaking, the social formation (in its Marxist meaning) had also become the decisive criterion of nationality. This new concept challenged widespread beliefs and incorporated national identities that were based on traditional nationalism. Historians have not yet sufficiently researched the adherence to the imagination of a united German nation in the GDR, but in 1989, when the people stood up and reclaimed their liberal rights, they soon imagined themselves as one, undividable people. First, they proclaimed "We are the people" then "We are one people." 63 Following other sources and findings, we argue that many in the GDR still imagined Germany as a national union; for them, it was an ethnic community that could not be separated by the claims of the socialist leaders. ${ }^{64}$

Nevertheless, none of the official parties or institutions stood for this understanding of a nation. The SED neutralized any form of opposition by forcing all other parties into the anti-fascist democratic bloc. Even the National Democratic Party of Germany (NDPD) did not gather a national opposition. Although the NDPD addressed former National Socialists above all, the SED soon incorporated this party into the bloc system, too. In the GDR, there was simply no institutional framework for nationalist politics. ${ }^{65}$

in Weimarer Klassik in der Ära Honecker, ed. Gunther Mai and Lother Ehrlich (Cologne/Weimar/ Vienna: Böhlau, 2001), 29-76.

62 Alfred Kosing, Nation in Geschichte und Gegenwart: Studien zur historisch-materialistischen Theorie der Nation (Berlin: Dietz, 1976); Alfred Kosing and Walter Schmidt, "Zur Herausbildung der sozialistischen Nation in der DDR,” Einheit 29 (1974): 179-188.

63 Konrad J. Jarausch, Die unverhoffte Einheit: 1989-1990 (Frankfurt: Suhrkamp, 1995); Andreas Rödder, Deutschland, einig Vaterland: Eine Geschichte der Wiedervereinigung (Munich: C.H. Beck, 2009).

64 As one example: Johannes Schütz, "Dresden bleibt deutsch?! Vorstellungen von nationaler Gemeinschaft im Bezirk Dresden, 1969-1990," in Freiheit, Angst und Provokation: Zum gesellschaftichen Zusammenhalt in der postdiktatorischen Gesellschaft, ed. Joachim Klose and Walter Schmitz (Dresden: Thelem, 2016), 48-57.

65 Christoph Wunnicke, Die Blockparteien der DDR. Kontinuitäten und Transformation 1945-1990 (Berlin: Der Berliner Landesbeauftragte für die Unterlagen des Staatssicherheitsdienstes der ehem. DDR, 2014); Christoph Schreiber, "Deutsche, auf die wir stolz sind": Untersuchungen zur NPDP (Hamburg: Dr. Kovac, 2018); Bernd Wagner, "Rechtsradikalismus in der Spät-DDR,” in Backes and Kailitz, Hochburg, 23. 
Aside from this official policy, several groups - or rather, most of the people in the GDR - still imagined themselves as German and still imagined Germany as a united community. They tried to transform the old nationalism into a new one, with greater or lesser degrees of success. The most effective way of identifying with the German nation was not by talking but by doing - and that was possible by creating the GDR as "Heimat" (home). Already in the 19th century, Heimat became the most important driver to translate the abstract imagery of a national community into local contexts. Heimat thus became a prerequisite for national integration by being the most important representation of the nation: Heimat was the hinge between the local area and the existing state. The numerous "Heimaten" made it possible, on the one hand, to be connected to the local area, but at the same time to create a community of all Germans. The nation was seen as a community of Bavarians, Wuerttemberger, and Saxons. It was only in this multitude of particular histories, dialects, and traditions that the German nation was constituted, and through the connection with the Heimat, a specifically German national consciousness was internalized. The Heimat movement then translated these images, narratives, and metaphors into concrete practices designing the respective Heimaten. ${ }^{66}$ Again, Saxony was at the core of this development. The Bund Heimatschutz was founded in Dresden in 1904, and the majority of clubs devoted to maintaining regional characteristics and traditions emerged in Saxony. ${ }^{67}$

The SED and the official politics of the GDR adopted this tradition of Heimat and transformed it for their purposes: from the 1960s, most of the Heimat practices in the GDR were only possible if they could be related to the development of socialism and the work of the party. Local chronologists, history teachers, and brigade leaders had to adhere to the linguistic order and the hierarchy of pictures in their activities; they had to be positive about the role of the SED, and in different extents, to the ideal overhang. ${ }^{68}$ But for the agents, Heimat was more than the socialist community - Heimat was the idea of keeping in touch with German history, German culture, and German traditions. Future research may show that, through the construction of their Heimat, many people in the GDR constructed a unified

66 Celia Applegate, A Nation of Provincials: The German Idea of Heimat (Berkeley: University of California Press, 1990); Alon Confino, The Nation as Local Metaphor: Württemberg, Imperial Germany and National Memory, 1871-1918 (Chapel Hill, NC/London: University of North Carolina Press, 1997).

67 Thomas Schaarschmidt, Regionalkultur und Diktatur. Sächsische Heimatbewegung und Heimat-Propaganda im Dritten Reich und in der SBZ/DDR (Cologne/Weimar/Vienna: Böhlau, 2004).

68 Jan Palmowski, Inventing a Socialist Nation: Heimat and the Politics of Everyday Life in the GDR, 1945-1990 (Cambridge: Cambridge University Press, 2013). 
German identity themselves. This room for imagination was unlocked at the beginning of the 1990s and is still open today. ${ }^{69}$

In addition, and in contrast to the officially legitimated discourse of Heimat, some individuals or small groups cultivated the National Socialist heritage. We have to notice here that there were some very active right-wing movements in the GDR who represented a radical nationalism. A comprehensive chronicle of right-wing extremist actions details how verbal and physical violence spread throughout the GDR in the 1980s. There were numerous attacks against "contract workers" from Vietnam, Mozambique, or Algeria, with violence and arson attacks on their homes and the direct use of force against them as well as against "punks" and "goths" in the GDR. Officially banned by the anti-fascist dogma of the GDR, anti-Semitism did not dominate the radical nationalistic worldview anymore. But from the top of the party down to the right-wing groups, we can trace antiSemitic speeches and actions. ${ }^{70}$

Although it is well known that there were possibilities of violence from the far right in the GDR, how these groups organized themselves in the GDR, which dynamics configured these processes, and which constellations determined the escalation have hardly been explored. ${ }^{71}$ We hypothesize that since these actors could not organize themselves in any institutional form, neither parties nor associations nor campaigns, they met primarily in groups who separated themselves from the West German parties by their explicit will to use violence. ${ }^{72}$

With the collapse of state power in the GDR, the right-wing street struggle escalated visibly and met those identified as foreign or political opponents almost daily. Hoyerswerda and Rostock-Lichtenhagen, for instance, are two East German cities that are well-known and connected to events in this series. Naming the cities

69 Johannes Schütz works in this field of research; his project at the University of Dresden is entitled "Polyphonie der Heimat. Konstruktionen von Gemeinschaft durch Imagination, Praktiken und Gefühle in Sachsen, 1969-2000."

70 Heike Radvan, “Das hat's bei uns nicht gegeben!” Antisemitismus in der DDR. Das Buch zur Ausstellung der Amadeu-Antonio-Stiftung (Berlin: Amadeu-Antonio-Stiftung, 2010); Harry Waibel, Die braune Saat. Antisemitismus und Neonazismus in der DDR (Stuttgart: Schmetterling, 2017); Wolfgang Benz, ed., Antisemitismus in der DDR. Manifestationen und Folgen des Feindbildes Israel (Berlin: Metropol-Verlag, 2018).

71 Yves Müller and Dominik Rigoll, "Rechtsextremismus als Gegenstand der Zeitgeschichte," Zeitgeschichte-Online, accessed February 6, 2020, https://zeitgeschichte-online.de/themen/re chtsextremismus-als-gegenstand-der-zeitgeschichte.

72 Not to mention the violent neo-Nazi groups that existed even in the FRG. Barbara Manthe, "On the Pathway to Violence. West German Right-Wing Terrorism in the 1970s," Terrorism and Political Violence 12 (2019): 1-22; Barbara Manthe, "Racism and Violence in Germany since 1980," Global Humanities: Studies in Histories, Cultures, and Societies 4 (2017): 35-53. 
serves to set markers in the national narrative of "reunification." Furthermore, and not included in this master narrative, East Germany became a place of violence in the years after 1990, and Dresden had its own role in this process: it was seen as the new capital of the movement (Hauptstadt der Bewegung). The most significant impact was the new confidence of the right political spectrum. In the 1990s and early 2000s, right-wing extremists demonstrated in Dresden on February 13, the day of the destruction of the city in World War II. By referring explicitly to the national socialist term Hauptstadt der Bewegung, some far-right politicians tried to unite the German nationalist groups of East and West in one party and thus regain discoursive and practical influence. The most extreme consequence was the violation of everyday life in unified Germany. Nationalists, patriots, or "Heimatschützer" (homeland protectors), as they called themselves, created violent nightmares and formed underground terrorist cells. Again, the homogeneous community was made the core of politics. Even if young radicals executed these politics, the ideas of national unity, sovereignty, and distinction, interpreted as ethnic homogeneity, were rooted in many different groups and actors of East Germany. Nationalism in this notion seeks to protect the "Heimat" and legitimizes violence. ${ }^{73}$ In 2011, the so-called NSU, the national socialist underground, revealed itself. These young East Germans were socialized in the disappearing GDR and transforming East Germany. ${ }^{74}$ They became part of the violent right-wing specter and, while hiding, conducted the program of leaderless resistance by murdering several Germans whom they regarded as migrants. This was the most extreme manifestation of radical nationalism in recent decades.

In the common politics and communication of everyday life, nationalism became stronger again. In different fields of public discourse, the nation took on a significant role in narrating the new unity of the states. What was German and how Germans defined themselves were part of vivid discussions, which infiltrated everyday life to a greater or lesser extent. ${ }^{75}$

This is one reason why nationalist parties had success in Saxony, Thuringia, and Brandenburg. Since the German unification in 1990, nationalist parties have infiltrated the political discourse with national phrases, and over the

73 Christian Schüle, Heimat. Ein Phantomschmerz (Munich: Droemer, 2017), 85-117.

74 Michael Lausberg, Die extreme Rechte in Ostdeutschland 1990-1998 (Marburg: TectumVerlag, 2012); Stefan Aust and Dirk Laabs, Heimatschutz: Der Staat und die Mordserie des NSU (Munich: Pantheon, 2014); Matthias Quent, Rassismus, Radikalisierung, Rechtsterrorismus: Wie der NSU entstand und was er über die Gesellschaft verrät (Basel: Beltz Juventa, 2019).

75 Konrad J. Jarausch, ed., After Unity: Reconfiguring German Identities (Providence/Oxford: Berghahn Books, 1997); Goetz, Deutsche Identitäten. 
years, they became more and more attractive to people in these regions, who were hardly met by local or global transformations. After the National Democratic Party of Germany (NPD) emerged, especially in some regions of MecklenburgVorpommern, Saxony, and Thuringia, and obtained many seats in communal and regional parliaments, ${ }^{76}$ now the Alternative for Germany (AfD) is proclaiming nationalistic discourse loudly and emphatically. Again, the nation is a socially relevant image for many Germans. ${ }^{77}$ They claim politics for Germans alone; they want to reserve social assurance for Germans alone, and - most importantly they aim to preserve "German culture," as they call it. All this by striving to make Germany homogenously white and German again. In summary, let us refer here to Christian Geulen again, who describes how the transformed nationalism unites in defence against anything foreign, but has no idea of what the nation has in common: "Die Nation, für die hier geworben und protestiert wird, ist eigentlich keine gegebene Partikularität mehr, sondern ein diffuses, aber umso flexibleres Programm der Stiftung von Gemeinschaftlichkeit durch Ausgrenzung und Anfeindung von allem, was irgendwie fremd erscheint."78

\section{Conclusion}

To sum up, we would like to make some concluding remarks on what these different forms of nationalism have in common. The presented nationalisms are united in their will to regard the nation as a homogenous group, often believed to be founded by the German people. They imagine this nation as threatened by enemies from outside and within; these could be the so-called Jewish world conspiracy, the Bolshevik revolution, Soviet puppets in the SED, or foreign workers in their community. In this way, these simple constructions of reality react to what we are all used to calling "modernity."

The example of Richard Guhr, who was conservatively socialized during the Empire, showed the authoritarian and anti-modern attitude of large parts of the population of Northeastern Germany, most of whom were Protestants. With the fall of the Empire in 1918, a supposedly intact world perished for them. For Guhr, the

76 Toralf Staud, Moderne Nazis: Die neuen Rechten und der Aufstieg der NPD, (Cologne: KiWi, 2006); Norbert Frei, Franka Maubach, Christina Morina and Maik Tändler, Zur rechten Zeit: Wider die Rückkehr des Nationalismus (Berlin: Ullstein, 2019).

77 Jay Julian Rosellini, German New Right: Afd, Pegida and the Re-Imagining of National Identity (London: Hurst \& Company, 2019).

78 Geulen, "Wiederkehr," 7. 
DNVP, and not least for the Nazis, the democracy of the Weimar Republic stood as an artificial construct dominated by Jews and external enemies through liberalism and communism. Thus, many non-democrats hoped that the so-called Third Reich would provide them with an ideological link to the Second Reich (1871-1918).

Nationalism was not dismissed after World War II in some German regions that are congruent with the former GDR. Instead, over the years, the nation has been transformed and become a powerful political resource that has deeply rooted itself in the GDR. Explicitly anti-Semitic notions were banned, though they were probably still held under the surface; the threat to the German people, however, was still a vivid phantasm of nationalistic discourse. After reunification in 1990, this nationalism unleashed itself in the East, and images of old and new enemies such as foreigners in general, Judaism, the EU, or Islam were presented.

\section{Works Cited}

Ahbe, Thomas. "Die Konstruktion der Ostdeutschen: Diskursive Spannungen, Stereotype und Identitäten seit 1989." Aus Politik und Zeitgeschichte 41, no. 42 (October 2004): 12-22.

Amos, Heike. Die SED-Deutschlandpolitik 1961-1989. Ziele, Aktivitäten und Konflikte. Göttingen: Vandenhoeck \& Ruprecht, 2015.

Anderson, Benedict. Imagined Communities: Reflections on the Origin and Spread of Nationalism. London: Verso, 1983.

Applegate, Celia. A Nation of Provincials: The German Idea of Heimat. Berkeley: University of California Press, 1990.

Assmann, Aleida and Ute Frevert. Geschichtsvergessenheit-Geschichtsversessenheit: Vom Umgang mit deutschen Vergangenheiten. Stuttgart: Deutsche Verlagsanstalt, 1999.

Aust, Stefan and Dirk Laabs. Heimatschutz: Der Staat und die Mordserie des NSU. Munich: Pantheon, 2014.

Backes, Uwe and Steffen Kailitz, eds. Sachsen - Eine Hochburg des Rechtsextremismus? Göttingen: Vandenhoeck und Ruprecht, 2020.

Bauer, Wolfgang. “Nachdenken über Bodo Uhse.” Das Blättchen 16, no. 14 (July 2013), accessed July 7, 2020, https://das-blaettchen.de/2013/07/nachdenken-ueber-bodouhse-25720.html.

Benz, Wolfgang, ed. Antisemitismus in der DDR. Manifestationen und Folgen des Feindbildes Israel. Berlin: Metropol-Verlag, 2018.

Bermbach, Udo. Richard Wagner in Deutschland: Rezeption - Verfälschungen. Stuttgart/ Weimar: Metzler, 2011.

Bewer, Max. Der Rembrandtdeutsche. Von einem Wahrheitsfreund. Dresden: Glöß, 1892. Bielefeld, Jörg. "Bismarcktürme- und Bismarcksäulen. Das Infoportal Bismarcktürme." Accessed July 7, 2020. https://www.bismarcktuerme.de/index.html.

Brajer, Sven. "Angst vor dem Fremden in Zeiten des Umbruchs? Aspekte von Antisemitismus und Rassismus im Kaiserreich in der Oberlausitz." Neues Lausitzisches Magazin 141 (2019): 81-92. 
Breuer, Stefan. Die Völkischen in Deutschland. Darmstadt: WBG, 2008.

Cantoni, Davide, Felix Hagemeister and Marc Westcott. "Persistence and Activation of RightWing Political Ideology.” Rationality and Competition, Discussion Paper No. 143 (February 2019): 1-44.

Chapoutot, Johann. Greeks, Romans, Germans: How the Nazis Usurped Europe's Classical Past. Berkeley: University of California Press, 2016.

Confino, Alon. The Nation as Local Metaphor: Württemberg, Imperial Germany and National Memory, 1871-1918. Chapel Hill, NC/London: University of North Carolina Press, 1997.

Curbach, Manfred, Thomas Hänseroth and Oliver Steinbock. "Willy Gehler in der Triade aus Wissenschaft, Industrie und Verwaltung." In Mit den wohlfeilsten Mitteln dauerhaft, feuersicher und bequem". Sparsamkeit als Prinzip, Rationalität als Weltsicht? (Schriftenreihe der Gesellschaft für Bautechnikgeschichte, vol. 2.), edited by Gesellschaft für Bautechnikgeschichte, 245-261. Dresden: Thelem, 2019.

Dasgupta, Rana. “The demise of the nation state." The Guardian, April 5, 2018. https://www. theguardian.com/news/2018/apr/05/demise-of-the-nation-state-rana-dasgupta.

Deutsche Wacht: Organ für nationale Politik; Publikationsorgan der völkischen Vereine Sachsens. Dresden: Verlag der Deutschen Wacht Volumes, 1879-1933.

Deutschen Sprachverein Dresden and Hermann Dunger, eds. Satzungen des Deutschen Sprachvereins. Neue Fassung von dem Beschlusse vom 17. Januar 1889. Dresden: Teich, 1889.

Esche, Alexandra. Hitlers "völkische Vorkämpfer". Die Entwicklung nationalsozialistischer Kultur- und Rassenpolitik in der Baum-Frick-Regierung 1930-1931 (Zivilisationen \& Geschichte, vol. 47). Berlin/New York: Peter Lang, 2017.

Fahrmeir, Andreas. Die Deutschen und ihre Nation: Geschichte einer Idee. Stuttgart: Reclam, 2017.

Feistel-Rohmeder, Bettina. "Kurzer Rückblick auf die Entstehung und Entwicklung der Deutschen Kunstgesellschaft." In Im Terror des Kunstbolschewismus.

Urkundensammlung des "Deutschen Kunstberichtes" aus den Jahren 1927-33, edited by Bettina Feistel-Rohmeder. Karlsruhe: Müller, 1938.

Fenske, Reiner. Imperiale Verbände im Deutschland der Zwischenkriegszeit im Vergleich. Die Beispiele des "Deutschen Ostbundes" und der "Deutschen Kolonialgesellschaft". Dresden: Diss, 2018.

Francois, Etienne, Hannes Siegrist and Jakob Vogel. "Die Nation. Vorstellungen, Inszenierungen, Emotionen." In Nation und Emotion. Deutschland und Frankreich im Vergleich 19. und 20. Jahrhundert, edited by Etienne Francois, Hannes Siegrist and Jakob Vogel, 13-35. Göttingen: Vandenhoeck und Ruprecht, 1995.

Frei, Norbert, Franka Maubach, Christina Morina and Maik Tändler. Zur rechten Zeit: Wider die Rückkehr des Nationalismus. Berlin: Ullstein, 2019.

Geulen, Christian. “Zur 'Wiederkehr' des Nationalismus.” Aus Politik und Zeitgeschichte 68, no. 48 (November 2018): 4-8.

Geulen, Christian. Wahlverwandte. Rassendiskurs und Nationalismus im späten

19. Jahrhundert. Hamburg: Hamburger Edition, 2006.

Goetz, Irene. Deutsche Identitäten: Die Wiederentdeckung des Nationalen nach 1989. Cologne/ Weimar/Vienna: Böhlau, 2011.

Guhr, Richard. Der Judenstil oder der Expressionismus. Dresden: Max Emil Fischer, 1922.

Guhr, Richard. Die Schuld am Verfall der Künste. Dresden: Fischer, 1923.

Guillaume, Damien. “Vers 'l'agitation antisémitique' comme phénomène transnational: hostilité antijuive, équivoques libérales et solidarité juive internationale de l’Affaire 
Mortara au Congrès de Berlin (1858-1878)." In Antisemitismus im 19. Jahrhundert aus internationaler Perspektive: Nineteenth Century Anti-Semitism in International

Perspective, edited by Mareike König and Oliver Schulz. Göttingen: V\&R Unipress, 2019. Hawes, James. The Shortest History of Germany. London: Old Street Publishing, 2017. Herbert, Ulrich. Geschichte Deutschlands im 20. Jahrhundert. Munich: C.H. Beck, 2014. Günther Heydemann, Jan Erik Schulte and Francesca Weil, "Sachsen und der

Nationalsozialismus: Zur Vielfalt gesellschaftlicher Teilhabe - Einführung," in Sachsen und der Nationalsozialismus, eds. idem (Göttingen: Vandenhoeck \& Ruprecht, 2014), 9-19.

Hobsbawm, Eric. Nationen und Nationalismus: Mythos und Realität seit 1780. Frankfurt a.M./ New York: Campus, 2006.

Hobsbawm, Eric. The Age of Extremes. A History of the World, 1914-1991. New York: Vintage Books, 1996.

Jacob, Frank. Die Thule-Gesellschaft. Berlin: uni-edition, 2010.

Jacob, Frank. Die Thule-Gesellschaft und die Kokuryûkai: Geheimgesellschaften im globalhistorischen Vergleich. Würzburg: Königshausen \& Neumann, 2013.

Jansen, Christian and Henning Borggräfe. Nation. Nationalität. Nationalismus. Frankfurt a.M./ New York: Campus, 2007.

Jarausch, Konrad J. Die unverhoffte Einheit: 1989-1990. Frankfurt: Suhrkamp, 1995.

Jarausch, Konrad J., ed. After Unity: Reconfiguring German Identities. Providence/Oxford: Berghahn Books, 1997.

John, Jürgen, ed. “Mitteldeutschland”. Begriff - Geschichte - Konstrukt. Rudolstadt/Jena: Hain-Verlag, 2001.

Jureit, Ulrike. "Ein Rhythmus der Geschichte? Generationsgeschichtliche Deutungsmuster zum 20. Jahrhundert." In Detlev Peukert und die NS-Forschung, ed. Rüdiger Hachtmann and Sven Reichardt, 88-94. Göttingen: Wallstein, 2015.

Kienemann, Christoph. Der koloniale Blick gen Osten. Osteuropa im Diskurs des Deutschen Kaiserreiches von 1871. Paderborn: Schöningh, 2018.

Köhler-Hausen, Ernst. Aus der Dresdner Wagner-Ehrung im Schloss Albrechtsberg. Dresden: Stadtmuseum, 1939.

Kolditz, Gerald. “Rolle und Wirksamkeit des Alldeutschen Verbandes in Dresden zwischen 1895 und 1918: ein Beitrag zum bürgerlichen Vereinsleben der nationalistischen Kräfte in der wilhelminischen Ära des deutschen Kaiserreiches." PhD diss., TU Dresden, 1994.

Kollmorgen, Raj. Ostdeutschland: Beobachtungen einer Übergangs- und Teilgesellschaft. Wiesbaden: Springer, 2005.

König, Christopher. Zwischen Kulturprotestantismus und völkischer Bewegung: Arthur Bonus (1864-1941) als religiöser Schriftsteller im wilhelminischen Kaiserreich. Tübingen: Mohr Siebeck, 2018.

Koselleck, Reinhart. “Volk, Nation. XV. Ausblick 1945-1991.” In Geschichtliche Grundbegriffe: Historisches Lexikon zur politisch-sozialen Sprache in Deutschland, vol. 7, edited by Otto Brunner, 420-430. Stuttgart: Klett-Cotta, 2004.

Kosing, Alfred and Walter Schmidt. "Zur Herausbildung der sozialistischen Nation in der DDR." Einheit 29 (Autumn 1974): 179-188.

Kosing, Alfred. Nation in Geschichte und Gegenwart: Studien zur historisch-materialistischen Theorie der Nation. Berlin: Dietz, 1976.

Kowalczuk, Ilko-Sascha. Die Übernahme. Wie Ostdeutschland Teil der Bundesrepublik wurde. Munich: C.H. Beck, 2019. 
Lächele, Rainer. “Protestantismus und Völkische Religion im deutschen Kaiserreich.” In Handbuch zur »Völkischen Bewegung « 1871-1918, edited by Uwe Puschner, Walter Schmitz and Justus H. Ulbricht. Munich: KG Saur, 1999.

Lausberg, Michael. Die extreme Rechte in Ostdeutschland 1990-1998. Marburg: Tectum-Verlag, 2012.

Lehmkuhl, Josef. Der Kunst-Messias: Richard Wagners Vermächtnis in seinen Schriften. Würzburg: Königshausen und Neumann, 2009.

Lemke, Michael. “Nationalismus im Deutschlandkonzept der SED 1949-1955.” In Nationalismus in Europa nach 1945, edited by Heiner Timmermann, 41-58. Berlin: Duncker und Humblot, 2001.

Louis, Rudolf. Die Weltanschauung Richard Wagners. Leipzig: Breitkopf \& Härtel, 1898.

Lowenstein, Steven M. et al. Deutsch-jüdische Geschichte in der Neuzeit: Umstrittene Integration 1871-1918. Munich: C.H. Beck, 1996.

Mai, Gunther. "Sozialistische Nation und Nationalkultur." In Weimarer Klassik in der Ära Honecker, edited by Gunther Mai and Lother Ehrlich, 29-76. Köln/Weimar/Wien: Böhlau, 2001.

Manthe, Barbara. "On the Pathway to Violence. West German Right-Wing Terrorism in the 1970s." Terrorism and Political Violence 12 (February 2019): 1-22.

Manthe, Barbara. "Racism and Violence in Germany since 1980." Global Humanities. Studies in Histories, Cultures, and Societies 4 (2017): 35-53.

McKay, Joanna. The Official Concept of the Nation in the Former GDR: Theory, Pragmatism and the Search for Legitimacy. Aldershot: Ashgate, 1998.

Meenzen, Sandra. “'Gutes Klassenbewusstsein, Parteiverbundenheit und Prinzipienfestigkeit': SED-Sekretäre mit NSDAP-Vergangenheit in Thüringen” [“Class consciousness, party alignment and adherence to Principles": Thuringian SED party secretaries with a NSDAP past]. Historical Social Research 35, no. 3 (2010): 59-63

Mergel, Thomas. "Das Scheitern des deutschen Tory-Konservatismus. Die Umformung der DNVP zu einer rechtsradikalen Partei 1928-1932." Historische Zeitschrift 276 (2003): 323-368.

Meuschel, Sigrid. Legitimation und Parteiherrschaft: Zum Paradox von Stabilität und Revolution in der DDR, 1945-1989. Frankfurt: Suhrkamp, 1992.

Müller, Yves and Dominik Rigoll. "Rechtsextremismus als Gegenstand der Zeitgeschichte.” Zeitgeschichte-Online, accessed February 6, 2020. https://zeitgeschichte-online.de/the men/rechtsextremismus-als-gegenstand-der-zeitgeschichte.

Ohnezeit, Maik. Zwischen "schärfster Opposition" und dem "Willen zur Macht" - Die Deutschnationale Volkspartei (DNVP) in der Weimarer Republik 1918-1928. Düsseldorf: Droste, 2011.

Palmowski, Jan. Inventing a Socialist Nation: Heimat and the Politics of Everyday Life in the GDR, 1945-1990. Cambridge: Cambridge University Press, 2013.

Piefel, Matthias. Antisemitismus und völkische Bewegung im Königreich Sachsen. Göttingen: V\&R Unipress, 2004.

Puschner, Uwe. "Deutsche Reformbühne und völkische Kultstätte. Ernst Wachler und das Harzer Bergtheater." In Handbuch zur "Völkischen Bewegung" 1871 - 1918, edited by Uwe Puschner, Walter Schmitz and Justus H. Ulbricht, 762-796. München: Saur, 1996.

Quent, Matthias. Rassismus, Radikalisierung, Rechtsterrorismus: Wie der NSU entstand und was er über die Gesellschaft verrät. Basel: Beltz Juventa, 2019.

Radvan, Heike. "Das hat's bei uns nicht gegeben!" Antisemitismus in der DDR. Das Buch zur Ausstellung der Amadeu-Antonio-Stiftung. Berlin: Amadeu-Antonio-Stiftung, 2010. 
Richter, Michael, Thomas Schaarschmidt and Mike Schmeitzner, eds. Länder, Gaue und Bezirke: Mitteldeutschland im 20. Jahrhundert. Dresden: Landeszentrale für politische Bildung, 2007.

Rödder, Andreas. Deutschland, einig Vaterland: Eine Geschichte der Wiedervereinigung. Munich: C.H. Beck, 2009.

Rosellini, Jay Julian. German New Right: Afd, Pegida and the Re-Imagining of National Identity. London: Hurst \& Company, 2019.

Rosenwein, Barbara. Emotional Communities in the Early Middle Ages. Ithaca, NY: Cornell University Press, 2006.

Schaarschmidt, Thomas. Regionalkultur und Diktatur. Sächsische Heimatbewegung und Heimat-Propaganda im Dritten Reich und in der SBZ/DDR. Cologne/Weimar/Vienna: Böhlau, 2004.

Schmid, Ulrich M. "Bismarck, eine Karriere - der «eiserne Kanzler» wird in Deutschland immer noch zu wenig kritisch gesehen.” Neue Zürcher Zeitung, January 20, 2020. https://www. nzz.ch/meinung/bismarck-eine-karriere-der-eiserne-kanzler-wird-in-deutschland-immernoch-zu-wenig-kritisch-gesehen-ld.1532085.

Schreiber, Christoph. "Deutsche, auf die wir stolz sind": Untersuchungen zur NPDP. Hamburg: Dr. Kovac, 2018.

Schüle, Christian. Heimat. Ein Phantomschmerz. Munich: Droemer, 2017.

Schütz, Johannes. "Dresden bleibt deutsch?! Vorstellungen von nationaler Gemeinschaft im Bezirk Dresden, 1969-1990.” In Freiheit, Angst und Provokation: Zum gesellschaftlichen Zusammenhalt in der postdiktatorischen Gesellschaft, edited by Joachim Klose and Walter Schmitz, 48-57. Dresden: Thelem, 2016.

Staud, Toralf. Moderne Nazis: Die neuen Rechten und der Aufstieg der NPD. Köln: KiWi, 2006.

Stiewe, Barbara. Der "Dritte Humanismus": Aspekte deutscher Griechenrezeption vom GeorgeKreis bis zum Nationalsozialismus. Berlin, Boston: De Gruyter, 2011.

Stummann-Bowert, Ruth. Ein Leben für Richard Wagner. Richard Guhr. Maler und Bildhauer 1873-1956. Fritzlar: Stiftung Museum Fritzlar, 1988.

Tanzmann, Bruno. "Zur Einleitung. Aus meinem Leben als völkischer Vorkämpfer." In Plan des Hochstiftes für Deutsche Art in Hellerau (Deutsche Bauernhochschule vol. 1), 1-2. 1926.

Thümmler, Jenny. “Heimatverein lädt zur Bismarckfeier." Sächsische Zeitung GOS Görlitz Lokales, March 31, 2015. https://www.saechsische.de/plus/heimatvereinlaedt-zurbismarckfeier-3072675.html.

Wagner, Andreas. “Machtergreifung” in Sachsen: NSDAP und staatliche Verwaltung 1930 1935. Cologne: Böhlau, 2004.

Wagner, Bernd. "Rechtsradikalismus in der Spät-DDR." In Sachsen - Eine Hochburg des Rechtsextremismus?, edited by Uwe Backes and Steffen Kailitz, 21-43. Göttingen: Vandenhoeck und Ruprecht, 2020.

Waibel, Harry. Die braune Saat. Antisemitismus und Neonazismus in der DDR. Stuttgart: Schmetterling, 2017.

Weber, Solveig. Das Bild Richard Wagners. Ikonographische Bestandsaufnahme eines Künstlerkults. Volume I: Text. Schott: Mainz, 1993.

Wehler, Hans-Ulrich. Nationalismus: Geschichte, Formen, Folgen. Munich: C.H. Beck, 2001. Wildt, Michael. Volk, Volksgemeinschaft, AfD. Hamburg: Hamburger Edition, 2017. Wunnicke, Christoph. Die Blockparteien der DDR. Kontinuitäten und Transformation 1945-1990. Berlin: Der Berliner Landesbeauftragte für die Unterlagen des Staatssicherheitsdienstes der ehem. DDR, 2014. 